\title{
A 2019-s csíksomlyói pápalátogatás: a sajtóanyagok elemzése
}

\author{
Kádár Beáta - Nagy Benedek \\ Sapientia - Erdélyi Magyar Tudományegyetem
}

\begin{abstract}
A TANULMÁNY CÉLJA
Tanulmányunk egy tágabb, komplexebb kutatás része, mely a 2019 június 1.-én lezajlott, történelmi eseménynek is tekinthető Ferenc pápa székelyföldi, csíksomlyói látogatásának körülményeit több módszerrel is meg kívánta vizsgálni. Jelen tanulmány célja elsősorban az, hogy a látogatás média leképeződését felfedje, megvizsgálja, hogy milyen módon tálalta az eseményt a nemzetközi, a magyarországi és a romániai román és magyar média külön-külön. Fontos kérdés, hogy kapott-e helyet ezekben a híradásokban, cikkekben Csík térség vagy a Székelyföld régió bemutatása vagy a Csíksomlyó szakrális és nemzeti-történelmi jelentősége, illetve milyen eltolódások vannak az egyes sajtóanyagok között.
\end{abstract}

\section{ALKALMAZOTT MÓDSZERTAN}

Mindezt úgy a kvantitatív tartalom elemzés, mind a kvalitatív elemzés módszerével, több, mint száz összegyűjtött sajtóanyag átvizsgálása révén tesszük meg.

\section{LEGFONTOSABB EREDMÉNYEK}

A sajtócikkek, melyek ma már többségükben elérhetőek a világhálón is, tekintélyes részletességgel tárgyalták a pápa csíksomlyói látogatását, azonban az esetek túlnyomó többségében ezek a cikkek a pápa üzenetére, esetleg aktuálpolitikai kérdésekre fókuszáltak, a székelyföldi vagy a csíki térség igen kevés figyelmet kapott. A román sajtó kimondottan keveset beszélt az etnikai-vallási sajátosságokról, az aktuális politikai diskurzus Romániában ugyanis nem túl kedvező és nem mondhatni túlzottan "magyarbarátnak" sem. Úgy tủnik, átfogó marketing koncepció, kommunikációs célok nem voltak megfogalmazva a térség sajátosságairól, a helyi társadalom életéről, szokásairól vagy más kérdésekről.

\section{GYAKORLATI JAVASLATOK}

Fontos, hogy az ilyen jellegű rendezvényekre marketing és kommunikációs szempontból lehetőségként tekintsenek a szakemberek, lehetőség a térség adottságainak népszerüsítésére, a turisták bevonzására vagy általánosan, a térség megismertetésére.

Kulcsszavak: pápalátogatás, Csíksomlyó, sajtóelemzés, tartalomelemzés, régió imázs, KH Coder

Köszönetnyilvánitás: A kutatás a Domus Hungarica 2019 szülőföldi csoportos ösztöndíjtámogatása révén valósult meg, a Videmus Papam elnevezésü kutatás keretén belül.

DOI: 10.15170/MM.2020.54.02.05 


\section{BEVEZETÉS INTRODUCTION}

A 2019-ben lezajlott romániai és azon belül a csíksomlyói pápalátogatás kapcsán nagyon nagy anyag született a hazai és a külföldi sajtó részéről is. Volt ahol az előkészületi munkálatokról számoltak be, voltak orgánumok, amelyek a pápa célállomásainak okait firtatták és voltak értelmezések, elemzések is, amelyek a pápa üzenetét, beszédét vagy más, nonverbális kommunikációját elemezték. A térség marketingjére és imázsára is jelentős hatással lehet egy ilyen esemény, nemcsak a résztvevők száma miatt, hanem a más, csak sajtóból és online média csatornákból értesülő nagyszámú érdeklődők miatt is. Fontosnak tartottuk ezért, hogy vizsgáljuk meg, hogyan tálalta a 2019-es romániai pápalátogatás csíksomlyói állomását a hazai román és magyar, a magyarországi, illetve a más, külföldi angol nyelvű média.

A sajtóelemzéssel kapcsolatban a következő kutatási kérdések merültek fel:

KK1. A Pápa Csíksomlyóra való látogatása kapcsán előtérbe kerül-e a sajtóban a kisebbségi magyarság, Székelyföld kérdése, illetve a Pünkösdi búcsúról is esik-e szó a médiában?

KK2. A regionális, romániai, magyarországi és nemzetközi sajtóban a Pápa csíksomlyói látogatásáról milyen hangvételü anyagok születtek?

KK3. Sikerült-e Csíkszeredáról és a térségéröl, mint turisztikai desztinációról valamilyen üzenetet eljuttatni a sajtóba? A régió imázsépítésének szempontjából ugyanis fontos kérdés, hogy mennyire kerül bemutatásra a vidék egy ilyen nagy horderejü esemény kapcsán.

\section{ANYAG ÉS MÓDSZER RESEARCH AND METHODOLOGY}

Mivel a digitális kommunikáció napjainkban már életünk minden területén meghatározóvá vált, nem történhet úgy nyilvános esemény, hogy annak sajtóvisszhangját mellőzni lehessen. Az új, hálózatba kapcsolt digitális platformok révén a kommunikáció könnyebbé vált, nagyobb rétegekhez jut el egy-egy sajtóanyag, és akkora hatása van, hogy a társadalomkutatóknak elemezni kell azt. A média nem csupán információt szolgáltat, hanem a keretberendezés, strukturális rendszerezés révén szervezett tudást nyújt a befogadónak. Egyes témákkal nagyobb terjedelemben foglalkozik, kidomborítja őket, míg másoknak egyáltalán nem, vagy csak minimális mértékben nyújt teret. A befogadók tudatában így tulajdonképpen napirendre tủz egy- egy témát, míg a többit háttérbe vagy kiszorítja ezt nevezi a szakirodalom a média napirendalkotó elméletének (McCombs \& Shaw 1972). Az egyes témák között tehát a médiumok létrehozzák a saját fontossági rangsoraikat, ami így az olvasó sorrendje is lesz. Így egyes nemzetközi sajtóorgánumok egymástól eltérő képet alkothatnak a jelen tanulmány tárgyát képező romániai pápalátogatásról is, politikai nézőpontjuk, nemzeti újságírói hagyományaik és más tényezők alapján. A kommunikáció módja pedig visszahat magára az eseményre, a vallásos szervezetekre, a vallási autoritásra és magára a vallásosság megélésére. Hiszen - mint a médiumelmélet egyik megalapítója, a jezsuita Walter Ong megjegyzi: „a különbözö médiumok különbözö típusú vallásosság kialakulását teszik lehetővé" (Ongot 1967, idézi Vedlinger 2005, 2). Tágabb értelemben a fenti megközelítések a vallás mediatizációjára vonatkozó médiaelméleti és vallásszociológiai paradigmába illeszkednek (Hjarvard 2008, 2011, Lynch 2011, Lövheim \& Lynch 2011).

A napirendalkotó szerep mellett a médiumok az alkalmazott értelmezési keret tekintetében is eltérnek egymástól. Ezek az értelmezési keretek egyfajta - nyílt vagy rejtett - erkölcsi értékítéletet is hordoznak (Entman 1993). A keretezés meghatározhatja az egyes események, történetek kiváltó okainak értelmezését is - nyíltan megnevezheti egy probléma okait, vagy rejtetten célozhat a kiváltó okokra. A keretezés alatt értett morális értékítéletet és az oksági magyarázatokat gyakran a média által használt nyelvbe, egy-egy kifejezésbe kódolva, rejtetten érhetjük tetten.

A pápalátogatás sajtóvisszhangjának elemzésénél az interneten is elérhető írott anyagokat elemeztük. Barajas et al. a 2010-es Santiago de Compostela-i pápalátogatás elemzése alapján jutott arra a következtetésre, hogy egy-egy ilyen jellegü, nemzetközi érdeklődésre is számot tartó eseményrôl az internetes sajtó teljesen átfogó képet közvetít (Barajas et al. 2014).

A romániai 2019-es pápalátogatás sajtóban való megjelenésének elemzése során több szempontot figyelembe vettünk, vizsgáltuk kommunikációs, turisztikai, etnikai és gazdasági szempontok alapján. A városimázs elemzésnél Irigoyen és társai következtetése szerint nemcsak a kifelé irányuló imázsépítést kell figyelembe vennünk, az elemzési szempontoknál a lakosokat célzó marketingeszközök és -üzenetek is fontosak (Irigoyen 2019).

Elemzésünk összesen 34 forrásból, a hazai, magyarországi és nemzetközi médiaszereplök legfontosabb képviselőitől gyüjtött 100 online formában is megjelent cikkre alapoz (1. táblázat), a következő megoszlás szerint: 
- $25 \mathrm{db}$ romániai magyar portálon megjelent cikk,

- $25 \mathrm{db}$. romániai román portálon megjelent cikk,
- $25 \mathrm{db}$. magyarországi magyar portálon megjelent cikk,

- $25 \mathrm{db}$. nemzetközi portálon, angolul megjelent cikk.

\section{1. táblázat: Az elektronikus sajtóból válogatott cikkek a google.com találatai alapján}

Table 1. Articles from the electronic press based on google.com results

\begin{tabular}{|c|c|c|}
\hline Ssz. & Angol nyelvü hírportálok & Az elemzésbe bekerült cikkek száma \\
\hline 1 & business-review.eu & 2 \\
\hline 2 & bbc.com & 1 \\
\hline 3 & rferl.org & 2 \\
\hline 4 & france24.com & 2 \\
\hline 5 & japantimes.co.jp & 1 \\
\hline 6 & euronews.com & 2 \\
\hline 7 & nytimes.com & 3 \\
\hline 8 & mx.news & 1 \\
\hline 9 & americamagazine.org & 1 \\
\hline 10 & apnews.com & 2 \\
\hline 11 & dw.com & 1 \\
\hline 12 & ncronline.org & 1 \\
\hline 13 & reuters.com & 1 \\
\hline 14 & news.yahoo.com & 1 \\
\hline 15 & balkaninsight.com & 1 \\
\hline 16 & citynews1130.com & 1 \\
\hline 17 & dw.com & 1 \\
\hline 18 & nbcnews.com & 1 \\
\hline Ssz. & Magyar nyelvủ romániai hírportálok & Az elemzésbe bekerült cikkek száma \\
\hline 19 & szekelyhon.ro & 7 \\
\hline 20 & transindex.ro & 4 \\
\hline 21 & kronika.ro & 6 \\
\hline 22 & maszol.ro & 6 \\
\hline 23 & szekelyfold.ma & 2 \\
\hline Ssz. & Román nyelvü hírportálok & Az elemzésbe bekerült cikkek száma \\
\hline 24 & libertatea.ro & 5 \\
\hline 25 & digi24.ro & 5 \\
\hline 26 & hotnews.ro & 1 \\
\hline 27 & antena3.ro & 4 \\
\hline 28 & adevarul.ro & 5 \\
\hline 29 & mediafax.ro & 5 \\
\hline Ssz. & Magyarországi magyar nyelvü hírportálok & Az elemzésbe bekerült cikkek száma \\
\hline 30 & index.hu & 6 \\
\hline 31 & hvg.hu & 6 \\
\hline 32 & origo.hu & 4 \\
\hline 33 & magyarnemzet.hu & 6 \\
\hline 34 & magyarkurir.hu & 3 \\
\hline
\end{tabular}

Forrás: saját szerkesztés 
A sajtóanyagok időben a pápalátogatás előtti egy hónapot és az azt követő egy hónapot ölelik fel. A Google online kereső segítségével a legnagyobb népszerüségnek örvendő portálok legnépszerübb cikkeit válogattuk be a Csíkszereda és a pápalátogatás címszavakat használva (románul, magyarul és angolul) a keresés során.

A sajtóanyagok elemzése során a $\mathrm{KH}$ Coder nevü tartalomelemző szoftvert alkalmaztuk. A tartalomelemzés ezen szoftveres formája a kvalitatív elemzési módszert igyekszik a kvantitatív elemzés irányába eltolni, beemelve a hálózatelemzést is. Az összes anyagot elöbb angol nyelvre kellett fordítani, mivel csak ezen a nyelven müködik a program. A szoftver segítségével a kiválasztott sajtóanyagokban fellelhető kulcskifejezések azonosítására, azok gyakoriságának vizsgálatára is lehetőség nyílik, elemezhetjük az egyes kifejezések közti kapcsolatokat, az együttes előfordulás gyakoriságát és különböző grafikus ábrázolások segítségével jól illusztrálhatók is ezen viszonyok. A sajtóanyagokat kvalitatív módon, átolvasással is próbáltuk elemezni és kiemelni a főbb mondanivalókat.

\section{A tartalomelemzés eredményei - Results of the content analysis}

Elsőként azt vizsgáltuk a KH Coder segítségével, hogy az egyes általunk meghatározott cikkcsoportokban (romániai magyar, román, nemzetközi angol, magyarországi magyar) mely fogalmak köré épül a kommunikáció és megnéztük ezen fogalmak együttes előfordulási együtthatóját (co-occurrence network). Minden cikk-csoportban azokat a kifejezéseket vettük figyelembe, amelyek min. 25-ször megjelennek a dokumentumban, a köztük lévő összefüggést a Jaccard együttható is mutatja, aminek ha nagyobb az értéke 0.1-nél egyértelmü összefüggés van a két kifejezés között.

1. ábra: Co-occurance network elemzés az angol nyelvü sajtócikkek alapján Figure 1. Co-occurance network research based on the English-language press articles
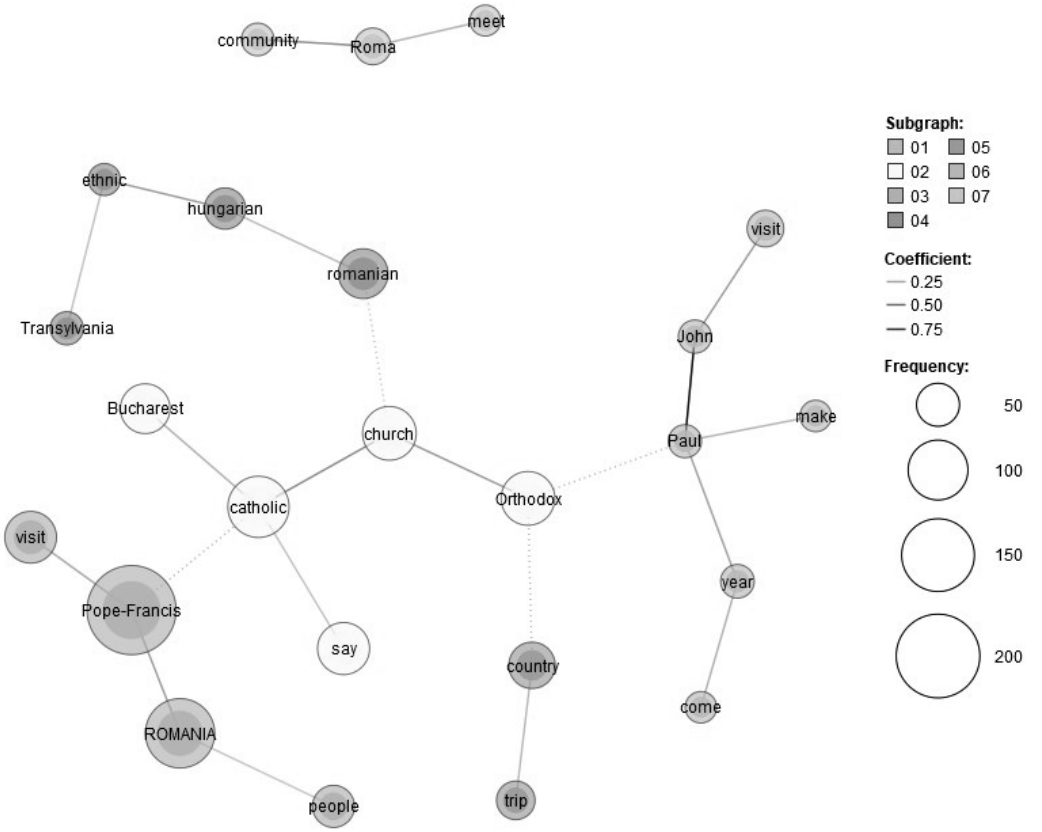

Forrás: saját szerkesztés a KH Coder alkalmazásával 
$\mathrm{Az}$ 1. ábra a nemzetközi sajtóban megjelent angol nyelvü cikkek elemzése során készült, bemutatja, melyek azok a fogalmak, amelyek köré épült a nemzetközi sajtóban a kommunikáció, illetve azt is mutatja, hogy milyen kapcsolat áll a fogalmak között, minél vastagabb egy vonal annál szorosabb a két fogalom közti kapcsolat, amelyeket összeköti. Láthatjuk, hogy hat fogalomcsoportot különített el az elemző program, egyik a Pápa neve és a romániai látogatás köré szerveződik, a másik a romániai főváros, Bukarest és az ortodox, katolikus közösség közé épül, míg jelentős a II. János Pál pápa látogatásának a felemlegetése is, továbbá helyet kap a kommunikációban a magyar etnikai kisebbség és Erdély is, illetve szinte ekkora súllyal említi a nemzetközi sajtó a roma kisebbséget is.

Az angol nyelvű cikkek többsége külföldi forrásból származik, van néhány, mely erdélyi vagy más romániai angol nyelvü portálról került be a cikkcsoportba. A cikkek többsége említi Csíksomlyót, mint egyik látogatási helyszínt, bár néhány éppen csak említi, semmilyen részletet nem közöl a helyszín etnikai, vallási vagy földrajzi sajátosságairól. A többségük azért leírja, hogy Csíksomlyó a romániai katolikus közösség fontos zarándokhelye vagy akár azt is, hogy ez a magyar katolikusság zarándokhelye. Ilyen értelemben itt-ott a román-magyar viszony érzékeny pontjai is elökerülnek, de ez nem jellemző. Néhány forrás esetében a magyarokról és Csíksomlyóról semmilyen szó nem esik (pl. bbc, nbc news, ncr online), csak a görög-katolikus szentté avatásról Balázsfalván vagy a roma közösséggel való találkozásról. Vannak viszont cikkek, amelyek rövid történelmi visszatekintésre is vállalkoznak (Erdély, Trianon stb.), máshol egyszerűen aktuálpolitikai értelmezéseket próbálnak adni (lásd a Euronews és a Reuters egyes anyagai) a pápa látogatásának (pl. Orbán Viktor határon túli politikája és a magyar kormány erdélyi támogatásai is felmerülnek). Egyetlen anyag beszél Csíkszeredáról, mint városról (balkaninsight). Néhány cikk Székelyföldet is említi, akár három nyelven is (france24, japantimes, yahoo), általában röviden vagy a székely zászlók kérdését és más regionális identitást érintő problémát is felvetnek (rferl / Szabad Európa).

Összességében elmondható, hogy az angol nyelvü anyagok sokszínüek, van amelyik említi a regionális és helyi sajátosságokat, máshol semmi nem hangzik el még az erdélyi magyarságról sem. Sajnos a régiót vagy a várost tematizáló cikkek „kisebbségben vannak”, tehát kevesebbet találtunk ilyent, azokhoz képest, amelyek keveset vagy semmit nem mondanak el a térségről vagy a nemzetiségi kérdésekröl.

2. ábra: Co-occurance network elemzés a magyarországi sajtócikkek alapján Figure 2. Co-occurance network research based on the Hungarian-language press articles

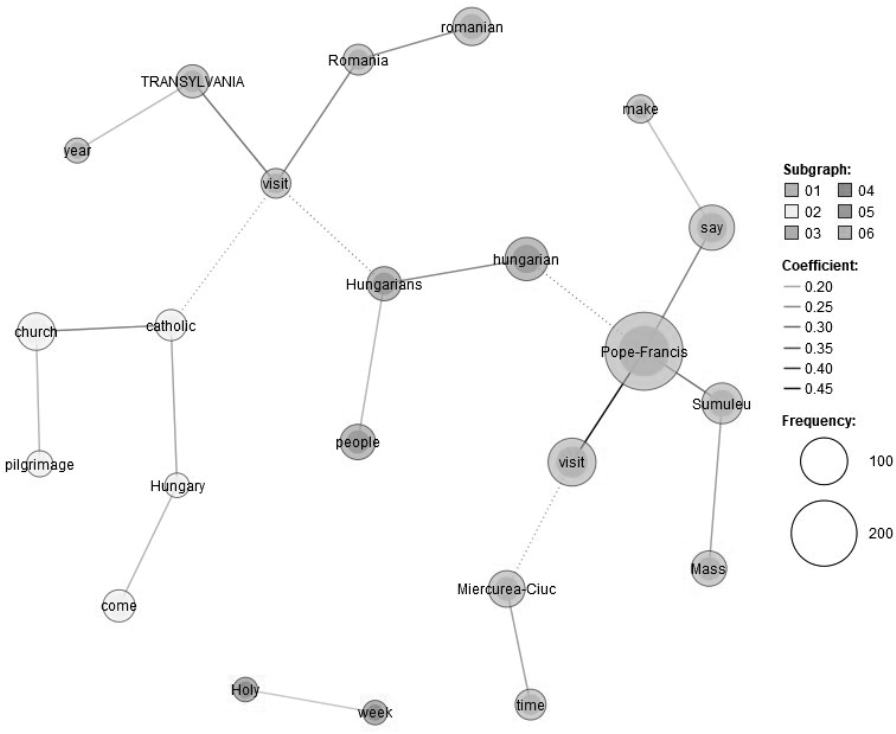

Forrás: saját szerkesztés a KH Coder alkalmazásával 
A magyarországi sajtó kommunikációjának elemzése a 2. ábrán látható, itt erőteljesen megjelenik Ferenc pápa neve mellett Csíksomlyó, Csíkszereda is a kommunikációban. Feltűnik Magyarország is és a zarándoklat fogalma, hiszen tény, hogy sokan eljöttek az anyaországból is a pápa csíksomlyói látogatására. Erdély Romániával egyenértékű említést nyert a magyar sajtóban, ami azt mutatja, hogy a magyar sajtó valamelyest említette a romániai látogatás más állomásait is.

A magyarországi cikkek csak öt forrásból (ld. 1. táblázat) származnak, de az idősáv, amit átfognak is sokkal szélesebb, mint a nemzetközi médiában átfogott expozíciós idő, hiszen már januárban jelzik a pápa romániai látogatásának eseményét, illetve találunk cikkeket június 10.-ről, tehát a látogatás után 10 nappal is. A magyarországi anyagok is sokfélék, változatosan tárgyalják a látogatás különbözö aspektusait, de nyilván sokkal részletesebbek, mint az angol/külföldi sajtócikkek, és mindenképpen érzékenyebbek az erdélyi magyar kérdésre, a csíksomlyói helyszín sajátosságaira vagy a látogatást megelőző elökészületekre. Relatív sok cikk született már a látogatást megelőzően, többnyire az előkészületekről, a magyar kormány támogatásáról és a készülő kulturális kínálatról is sokat írtak. A látogatásról rendszerint úgy beszélnek, mint egy 100 ezres embertömegröl, a román miniszterelnök és a magyarországi köztársasági elnök jelenlétéről, illetve ezek politikai jelentőségéről. Előkerülnek egyes cikkekben a román hatalmi szervek visszaélései is, elsősorban a miseruha magyar feliratának a letakarása, a regisztrációhoz és más bonyodalmakhoz kötött beléptetés, az újságíróknak fenntartott nevetségesen kis hely stb. Az esemény „utógondozása" is érdekes, hiszen a látogatást követö napokban említést nyer Ferenc pápa köszönőlevele az erdélyi érseknek, a hálaadó mise a látogatásért vagy a székely család - mely ajándékot adott át a pápának - élményének feldolgozása. Fontosnak tartjuk a hellyel kapcsolatos jelzőket is megemlíteni: Csíksomlyó, ahol él a népi vallásosság, a legautentikusabb hely (index.hu), Csíksomlyó, mint a magyarság legfőbb zarándokhelye (magyarnemzet. hu). Mindezzel együtt a magyarországi cikkek sem beszélnek sokat a helyröl, sem a városról (Csíkszeredáról), sem Csíksomlyóról, sem pedig a térségről (Hargita megyéről vagy Székelyföldről).
Összegezve, ha a magyarországi cikkeket átnézzük azt tapasztaljuk, hogy itt már egyértelmü a Csíksomlyó és a látogatás itteni eseményeinek a túlsúlya, ami azt az érzést keltheti egy átlag magyar olvasóban, hogy ez volt az egyedüli vagy mindenképp a látogatás fő célpontja, ami nyilván ebben a formában nem igaz. Bár megjegyzi az egyik szerző/ elemző a pápa nem Erdélybe vagy Csíksomlyóra látogat, hanem Romániába (index.hu), a cikkek tematikája azt érzékelteti, hogy a csíksomlyói látogatás volt a legfontosabb.

A romániai magyar sajtóban megjelent cikkek szoftveres elemzésén látszik leginkább, hogy a pápalátogatással kapcsolatos sajtóközlemények nem voltak kulcsszavak szintjén is átgondolva (3. ábra). Az a tény, hogy a Románia helynév többször szerepel mint a Csíkszereda vagy a Csíksomlyó, vagy hogy ez utóbbiakhoz nem kapcsolódik valamilyen markánsabb jelző vagy határozó (pl. katolikus, magyar, székely stb.) mind jelzi a nem tudatos kommunikációt. Láthatjuk, hogy nem kerül kellő súly a kisebbségi fogalmakra sem. A következtetésünk tehát az lehet, hogy bár valószínủ tényszerüen közölte az előkészület fejleményeit a romániai magyar sajtó, addig mégsem jutottak el, hogy a kommunikációt azon fogalmak és üzenetek köré építsék, amelyeket egy ilyen horderejü és ekkora olvasottságra számot tartó rendezvény kapcsán fontos lenne kommunikálni a világ felé. 


\section{3. ábra: Co-occurance network elemzés romániai magyar sajtó kommunikációja alapján \\ Figure 3. Co-occurance network research based on the Hungarian-language press articles from Romania}

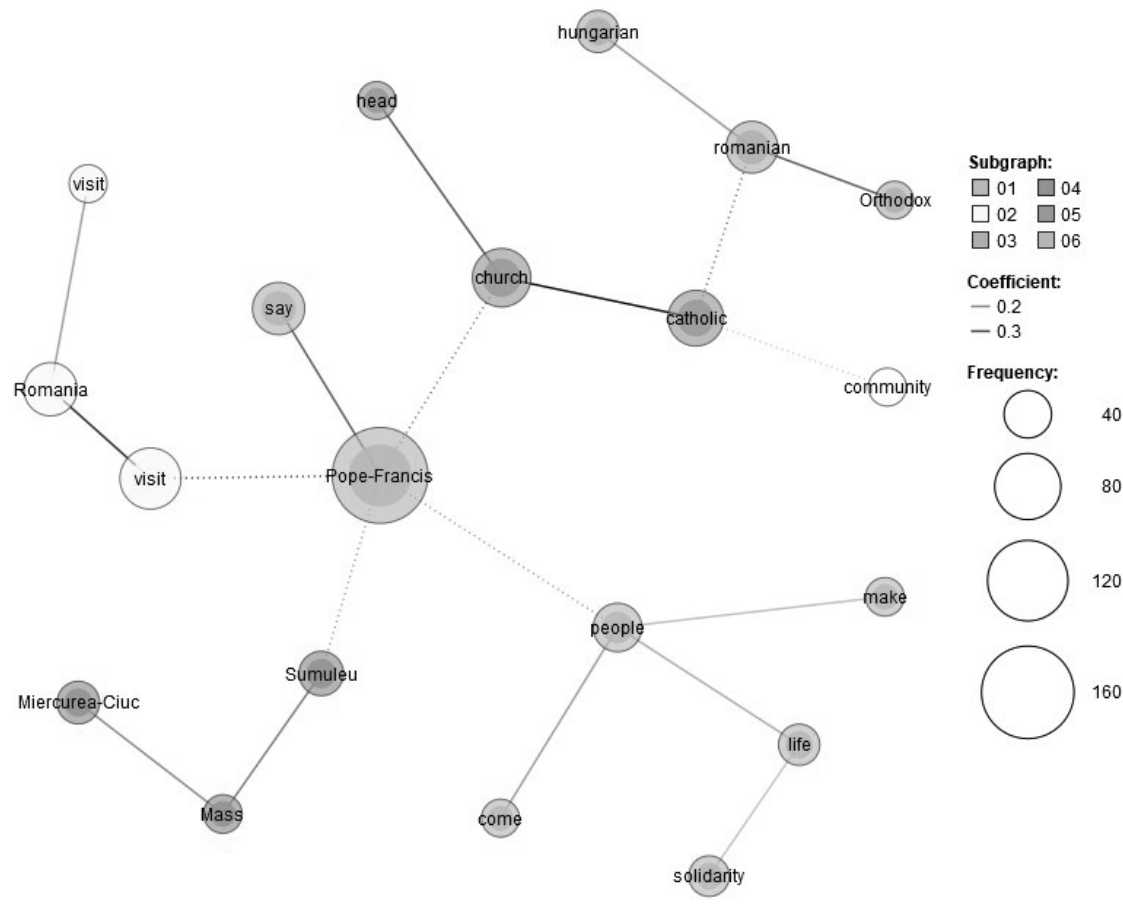

Forrás: saját szerkesztés a KH Coder alkalmazásával

Kvalitatív módon elemezve a romániai magyar cikkeket itt is Csíksomlyó prezentációkat találunk túlsúlyban, de nyilván ezek a cikkek - amiket szintén öt forrásból gyüjtöttünk össze - a legrészletesebbek, és a legtöbb olyan témát tartalmazzák, amik más anyagokban nem jelennek meg. Sok kis előkészületről, mikrótörténetröl szerzünk tudomást, több elemzés is megjelenik az esemény jelentőségéröl. Ilymódon több cikk születik a székelykapu felállításáról, a Hármashalom-oltár felújításáról és bővítéséről, a tevezett beléptetőkapukról és a regisztráció kérdéséröl (kezdetben kötelezőként jelentik be, később jelzik, hogy enélkül is részt lehet venni), a Mária-kegyszobor ideiglenes kiköltöztetéséröl a nyeregbe, a miseruha magyar feliratának a letakarásáról stb. Az esemény méretei kapcsán visszafogott a romániai magyar sajtó, relatív kevés létszámbecslés lát napvilágot, mondhatni furcsa módon, talán azért, mert érezhetően alacsonyabb volt a jelenlét, mint az kezdetben elörelátott volt. A látogatás napján nem lehetett véka alá rejteni a szakadó esőt, de ezt is, mint közösségi erőpróbát - melyet sikeresen teljesített az erdélyi és főleg a helyi közösség mutatják be. Az eseménynek tehát összességében pozitív kicsengése van, noha, az erdélyi sajtóban látszottak leginkább a kellemetlenségek is. Ez némiképp többet beszél (mint a magyarországi) a más helyszínekről, elsősorban a látogatás bukaresti állomásairól, de a balázsfalvi momentumokról is, kétszer is említik a pápa roma közösséggel való találkozását. A pápa személyére vonatkozó kritikák vagy ellentmondások kevésbé jelennek meg az erdélyi magyar sajtóban, mint a magyarországi sajtóban. 
4. ábra: Co-occurance network elemzés román sajtó kommunikációja alapján Figure 4. Co-occurance network research based on the Romanian-language press articles

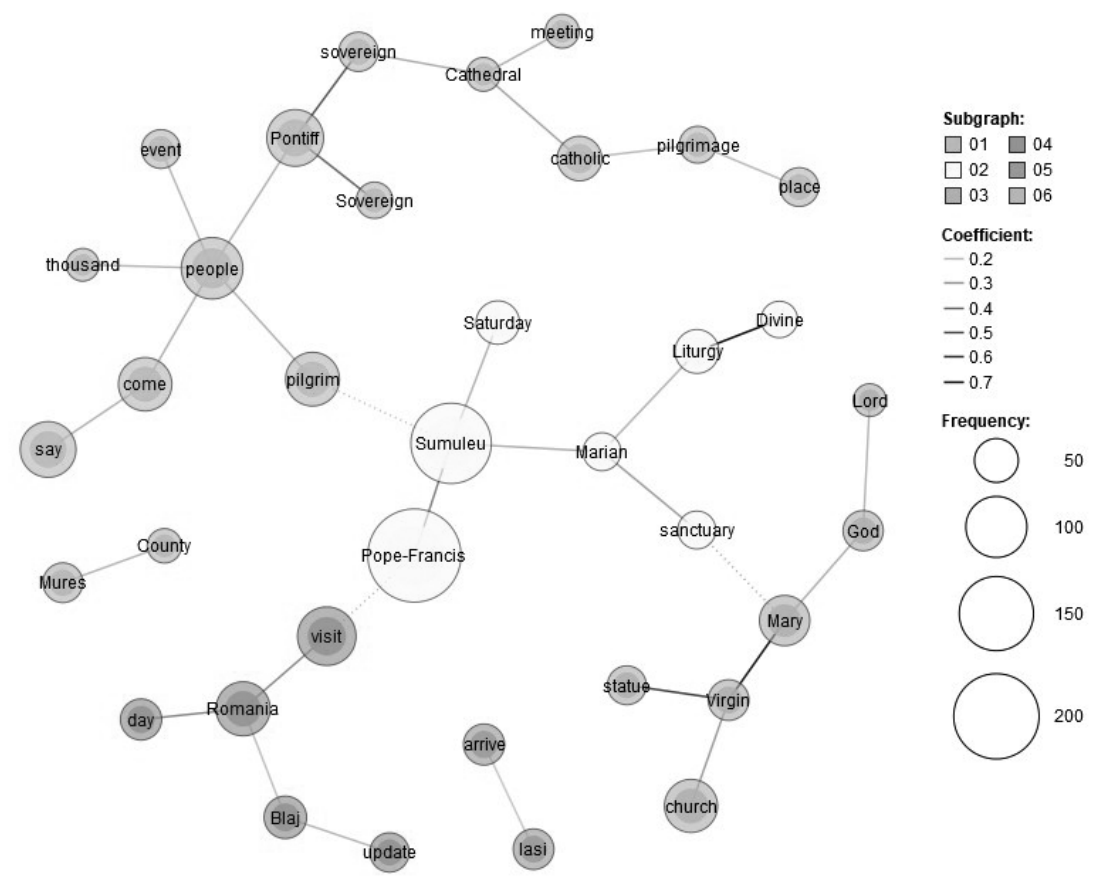

Forrás: saját szerkesztés a KH Coder alkalmazásával

A román sajtó kommunikációjában látszólag egyáltalán nem jelenik meg Székelyföld és Erdély, viszont Csíksomlyó jelentős figyelmet kap, emellett megemlítendő a Szűz Mária szobornak a leírásai, illetve a Pápa által hozott aranyrózsa ajándékról is beszámoltak. Emellett jelentős szerephez jut a balázsfalvi, jászvárosi látogatás is, pedig a keresés elsősorban a csíksomlyói látogatásra vonatkozott.

A román sajtó részletes, kvalitatív elemzése során teljesen más képet kapunk az eseményről és a térségről is, mint a romániai magyar vagy a magyarországi magyar sajtóból. Sokat foglalkozik a román sajtó pl. a pápa üzenetével, aminek különféle interpretációkat is adnak a békés együttélésröl, Somlyó, mint a testvériség szimbóluma és ehhez hasonló olvasatokkal találkozunk. Kiemelik, hogy a pápa beszédében megjelent a somlyói zarándoklat értékelése, mint erdélyi örökség, de egyben román és magyar hagyomány is (...). Vannak cikkek, amelyek említést sem tesznek Somlyóról, csak Balázsfalváról, mint a látogatás „csúcspontjáról”. Viszonylag sok cikk volt az elökészületekröl, az áramvezetésről a Hármashalom-oltárhoz, a tüzoltókocsikról vagy az oltár felújításáról. Többször előkerül a látogatók várható (40 000) vagy tényleges létszáma is (85000 fó - kérdés, hogy miért és honnan jelenik meg ez a viszonylag pontos szám, de több román cikkben is ezzel találkozunk). Többen említik a magyarországi köztársasági elnök jelenlétét, különösebb konotáció nélkül. Egyik elemző szerint külön értékelendő, hogy nem volt (túl sok) magyar és székely zászló. Ami viszont szembetünő, hogy sehol a hely (Csíksomlyó vagy Csíkszereda) magyar jellege nem derül ki, a székelykapu is csak „csíki” szimbólom. Sokszor bemutatják a Mária-kegyszobrot (egyik helyen hibásan, ,ikon”-ként), többnyire részletesen, a kapcsolódó legendákkal együtt, de nincs szó arról, hogy itt magyarok laknának vagy ez a magyar közösség öröksége lenne. A hely magyar jellegére csupán a pápa románul és magyarul is elmondott beszédéböl lehet következtetni, amit két cikk is beépít a tartalmába. Ugyanígy a miseruha, mint egy román 
iparművész alkotása is többször előkerül, de ennek kényes kérdéséről, azaz a magyar felirat letakarásáról nem esik szó sehol, annak ellenére, hogy ezt maga az iparművész is kifogásolta akkor. Többször beszámolnak a hipotermiás és a más ellátásra szoruló esetekröl, a látogatás utáni cikkekben, van ahol 260 ilyen esetről, máshol kevesebbről beszélnek.

Összességében az olvasható ki a román cikkekből, hogy a somlyói látogatás egy roppant nehéz pillanata volt a teljes romániai látogatásnak, szakadó esőben, sok hipotermiás és más sérült esettel, de alapvetően a legtöbb cikk próbált objektív lenni, leszámítva azt, hogy a város vagy Csíksomlyó, vagy akár a búcsú magyar kapcsolódásait teljesen mellőzik (egyetelen cikk jelenti, hogy ez egy 450 éves katolikus búcsújáró hely). A pápa somlyói misebeszédéből sokat idéznek, néha értelmezésekkel is, illetve az aranyrózsa ajándékot is rendszerint megemlítik.

A nyelvi bontásban végzett elemzés után kíváncsiak voltunk, hogy alakul az egyes kifejezések súlya a teljes sajtóanyagot bevonva. Érdekes, hogy János Pál pápa látogatása még az összesített elemzésben is helyet kap, és több fogalom megjelenik, amelyek a csíksomlyói kegyhely leírására vonatkoznak, mont például a Szüz Mária szobor fogalma köré csoportosított kifejezések. Ebben az elemzésben már helyet kapnak az ország elöljárói, akik fogadták a pápát vagy részt vettek a látogatásain. Székelyföldről más kifejezés nem került be így az elemzésbe, csupán Csíksomlyó, mint a pápa egyik látogatásának helyszíne. Ezt nem kell különleges eredménynek tartanunk, hiszen, ahogy az elemzési módszer bemutatásánál is leírtuk, eleve próbáltuk a csíksomlyói látogatást is említő cikkeket beválogatni az elemzésbe. Ugyanakkor a témák elkülönülve, egymástól kvázi függetlenül jelennek meg, úgymint a balázsfalvi látogatás, az ortodox pátriárkával való találkozás, a csíksomlyói látogatás és ettől szintén különállóan, kis súllyal a csíksomlyói hegynyereg és az ott található oltár, valamint külön a Mária-szobor és a Mária-kultuszt ápoló ferences rend.
Korrespondencia-elemzéssel is megvizsgáltuk az adatbázist, ami az 5. ábrán bemutatott eredményt hozta, tulajdonképpen azt látjuk, hogy az egyes nyelven íródott cikkek milyen fogalmak alapján vannak felépítve. Az elemzés alapján elkülönül a magyarországi magyar sajtó kommunikációja, amely az elöző és a jelen elemzés alapján is tudatosan használva a magyarság, Csíkszereda, Erdély fogalmakat épít a romániai magyar kisebbség hangsúlyozására. Itt is az bizonyosodik be, hogy a romániai magyar sajtó teljesen más szempontokra helyezte a hangsúlyt, így nem kerültek be a legnépszerübb szavak közé a székelységre, Erdélyre, a romániai magyar kisebbségre vonatkozó fogalmak, ök a látogatást, Ferenc pápát, a Vatikánt és a zarándoklatot hangsúlyozták leginkább. A nemzetközi és a román sajtó a tényközlésre fókuszált, említik a legfontosabb helyszíneket, ahová ellátogatott a Pápa, említik az ország felekezeti megoszlását, a katolikus és ortodox híveket, továbbá kiemelendő a Szüz Mária (szobor?) hangsúlyozása a román sajtó részéről. 


\section{5. ábra: Korrespondencia-elemzés a sajtóadatbázis alapján Figure 5. Correspondance analysis based on the involved articles}

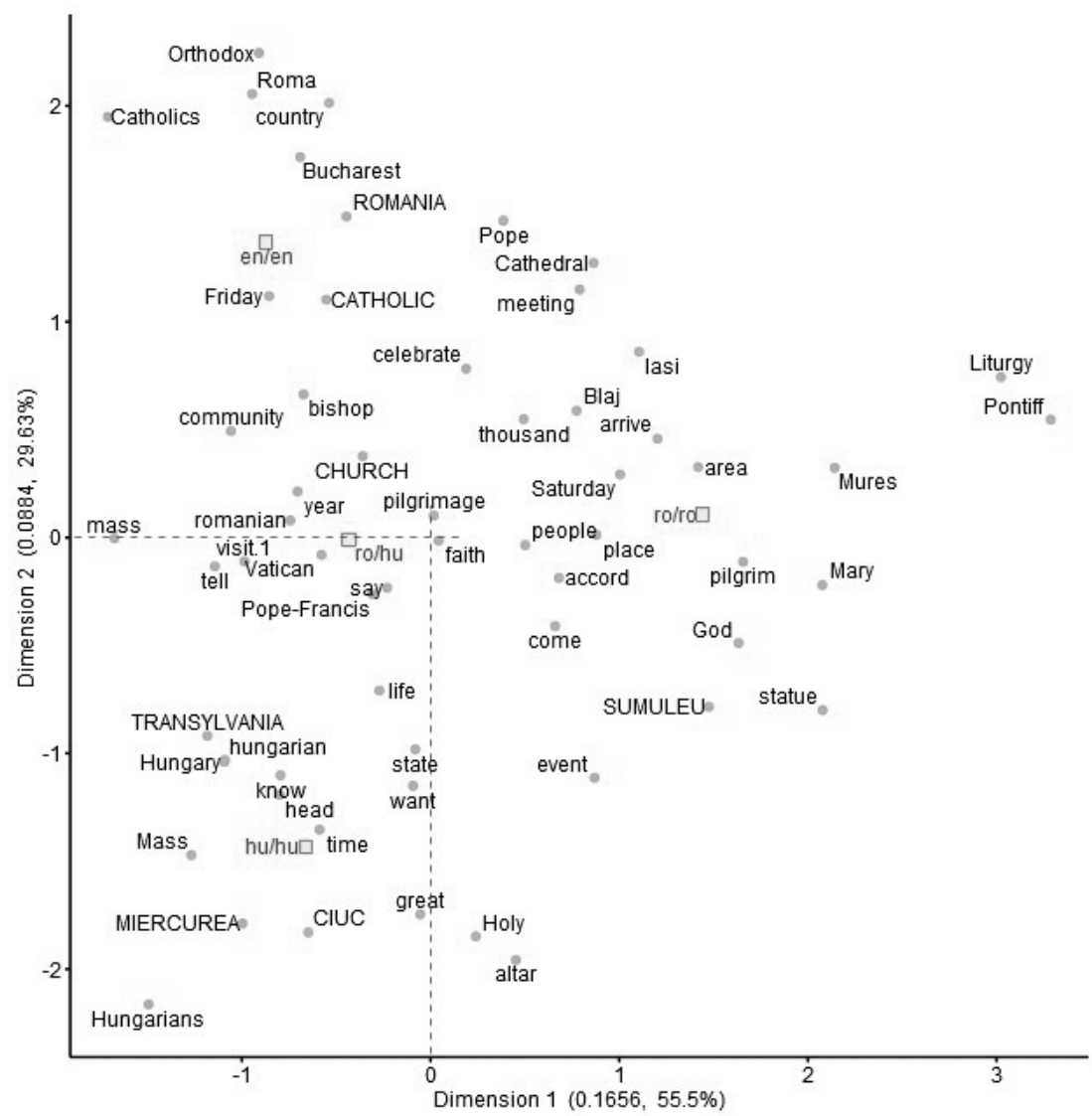

Forrás: saját szerkesztés a KH Coder alkalmazásával

A KH Coder szoftver kereszttábla elemzését használva a székely / Székelyföld, Pünkösd, magyarság és Csíksomlyó fogalmak gyakoriságát vizsgáltuk az egyes hírportálokon. Az eredmény: a székely és Székelyföld fogalmak a magyar sajtóban jelennek meg hangsúlyosabban, és nagyon kis mértékben a román sajtóban (mindösszesen 2 sajtóorgánumban), míg a nemzetközi sajtót tekintve a france24 említi még. Csíksomlyó hangsúlyos, szinte minden sajtóorgánum említést tesz róla, jelentős mértékben. A magyarok/ magyarság fogalmak szintén hangsúlyosak számszerileg és a megoszlást tekintve egyaránt. Kíváncsiak voltunk még arra, hogy összekötik-e a Pünkösdi búcsút a pápalátogatással, tekintve, hogy eddig Csíksomlyó a Pünkösdi búcsú zarándokhelyeként volt ismert és tavaly egy hét választotta el a két eseményt egymástól. Meglepő módon több román és nemzetközi sajtóorgánum is említette a búcsút is.

A négy cikkcsoportot együtt elemezve megállapítható, hogy eltérések vannak mind a menynyiségi, mind a minőségi, tartalmi kérdésekben is ezek között, bár a cikkcsoportokon belül sincs homogenitás, nyilván. A külföldi források inkább rövid, tárgyilagos vagy inkább távolságtartó - néhol (ritkán) kis politikai értelmezésekkel is tarkított cikkeket közöltek, közvetlenül az esemény előtt vagy után. Kevés szó esik ezekben a helyszínröl, ennek vallási vagy világi jelentőségéről, sajátosságairól. A romákkal való kapcsolatfelvétel nagyobb figyel- 
met kap, mint az erdélyi magyarság. A magyarországi sajtó is többnyire objektíven jeleníti meg az eseményt, de itt a magyarság, magyar jelleg erősebb, és már a hatalmi visszaélések is szóba kerülnek.

Egy kissé viszont egyoldalú, kevés szó esik a látogatás többi helyszínérôl és ezek más politikai-diplomáciai jelentős tartalmairól. Az erdélyi magyar sajtóban minden található, de itt a visszafogottság, óvatosság a jellemző. Nyilván a térség bemutatása itt kevésbé fontos, hiszen ez az erdélyi magyarság számára jól ismert helyszín (talán ez alól kivétel egy visszajelzés említés Ferenc pápa részéről, aki a hazautazása során állítólag azt mondta Erdélyről, hogy „csodálatos hely, ehhez foghatót még nem láttam" - ez fontos önképet kiegészítô-erősítő imázselem lehet). A politikai-diplomácia értelmezések is helyet kapnak, a pápa üzenetével is foglalkoznak, csakúgy, mint a román karhatalmi erök részéről ért sérelmek. Ami még fontos, hogy azért a romániai magyar sajtó némileg a más helyszínekre tett látogatásról is beszél, nyilván nem annyit, mint Csíksomlyóról vagy amennyit a román sajtó ezt teszi. A román sajtó a csíksomlyói látogatást elég pozitívan kezeli, bár a szabadtéri, esős helyszín és a hipotermiás esetek itt kapnak a legnagyobb visszhangot. Ugyanakkor a magyar örökség-jelleg teljesen kimarad minden cikkben, ezek alapján akár román katolikus vidék is lehetne Csíksomlyó, egy teljesen tudatlan román olvasó számára. Sőt, egyik elemző katolikus „hittérítésről", misszóról beszél és a pápalátogatást alapvetően offenzív, nyugati hatalmak által kitervelt hódító müveletként tünteti fel. A többség azonban a pápa beszédéből a (román-magyar? - ez nincs kimondva) megbékélés és békés együttélés üzenetét emeli ki. A román sajtó nem kerüli ki Csíksomlyót, de nem is ad neki különösebb jelentőséget.

\section{KÖVETKEZTETÉSEK ÉS JAVASLATOK CONCLUSIONS AND RECOMMENDATIONS}

Következtetésképpen elmondhatjuk, hogy tudatos kommunikáció nem volt felépítve a szervezők részéről a térséggel kapcsolatban, ami kívánatos lett volna elsősorban a nyugati, külföldi sajtószereplök felé. Bár ezek helyenként foglalkoznak Székelyfölddel, a többségük említést sem tesz a magyar etnikumról vagy az erdélyi magyarság problémáiról, érzékeny kérdéseiröl.
A sajtócikkek, melyek ma már többségükben elérhetőek a világhálón is, tekintélyes részletességgel tárgyalták a pápa csíksomlyói látogatását, azonban az esetek túlnyomó többségében ezek a cikkek a pápa üzenetére, esetleg aktuálpolitikai kérdésekre fókuszáltak, a székelyföldi vagy a csíki térség igen kevés figyelmet kapott. A román sajtó kimondottan keveset beszélt az etnikai-vallási sajátosságokról, az aktuális politikai diskurzus Romániában ugyanis nem túl kedvezö és nem mondhatni túlzottan "magyarbarátnak" sem. Az előkészületek, az eseményt megelőző jelentős beruházások viszont némi figyelmet kiérdemeltek, főleg a magyar sajtó részéről, ami természetes is, hiszen a felkészülés a kulturális programok egy jó részét jelentős mértékben támogatta a magyar kormány. A külföldi cikkek általában szükszavúan és inkább a diplomáciai-egyházpolitikai kérdésekre fókuszáltak (ortodox-katolikus viszony, II. János Pál pápa óta eltelt fejlemények, roma találkozó), kevésbé a térség sajátosságaira. Tehát vélhetően nagy imázsváltozást a pápa csíksomlyói látogatása nem idézett elő nemzetközi viszonylatban, de azért az kiderült általában, hogy a pápa ellátogatott egy magyar közösséghez, magyar katolikus zarándokhelyre is, ekképpen "kanonizálta" Csíksomlyót is, mint "pápai helyszínt". A román közvélemény is kaphatott több pozitív élményt, hiszen az is megtörténhet, hogy eddig semmit sem hallottak Csíksomlyóról (a román szakirodalom sem igen ismeri, pl. több zarándokturizmust elemző romániai cikk is teljsen kifelejti - Negrusa - Toader 2014, Giusca et al. 2018).

A pápa látogatása, ennek kapcsán pedig a pünkösdi zarándoklat és a kegyszobor részletes bemutatása - akár az etnikai-vallási sajátosságok nélkül is - fontos imázselem lehet egy későbbi (ökumenikus) vallásturizmus kialakulásában, amely immár magába foglalhat görög-katolikus és görög-keleti, román nemzetiségủ híveket is (erre utaló jelek vannak, pl. a kegyhelyet fenntartó ferences szerzetesek elmondása szerint a pápalátogatás óta érezhetően több a román ajkú látogató a templomban). Konkrét információnk nincs az imázsváltozásról, de jó eséllyel ma már több román hallott Csíksomlyótól, illetve vélhetően többet tudnak a több tíz megjelent cikk hatására, még ha ezek csak a szokásos “háromnapos csoda" kategóriában is maradtak. 


\section{HIVATKOZÁSOK REFERENCES}

Barajas, A., Lago-Peñas, S. and Sanchez, P. (2014), "On the regional economic effects of the Pope's journeys: evidence from the visit to Santiago de Compostela in 2010", Tourism Economics, 20(2), 279-299 DOI: 10.5367/te.2013.0270

Entman, R. M. (1993), 'Framing: Toward Clarification of a Fractured Paradigm", Journal of Communication, 43(4), 51-58 DOI: 10.1111/j.14602466.1993.tb01304.x

Giusca, M..C., Gheorghilas, A and, Dumitrache, L. (2018), "Assessment of the religious-tourism potential in Romania", Human Geographies - Journal of Studies and Research in Human Geography, 12(2), 225-237 DOI: 10.5719/ hgeo.2018.122.6

Hjarvard, S. (2008), "The Mediatisation of Religion. The Theory of the Media as Agents of Religious Change", Northern Lights, 6(1), 9-26 DOI: 10.1386/nl.6.1.9/1

Hjarvard, S. (2011), "The Mediatisation of Religion: Theorising Religion, Media and Social Change", Culture and Religion, 12(2), 119-135 DOI: 10.1080/14755610.2011.579719

Irigoyen, C. O., Neulinger Á., Molnár-Csomós I. (2019), „Egy nagyszabású rendezvény hatása a rossz városimázsra: Ferenc pápa látogatásának befolyása Juarez város megítélésére", Turizmus Buletin, XIX(2), 24-33

Lynch, G. (2011), "What Can We Learn from the Mediatisation of Religion Debate?", Culture and Religion, 12(2), 203-210 DOI: 10.1080/14755610.2011.579714

Lövheim, M. and Lynch G. (2011), "The Mediatisation of Religion Debate: An Introduction", Culture and Religion, 12(2), 111-117 DOI: 10.1080/14755610.2011.579715

McCombs, M. E. and Shaw L. D. (1972), "The Agenda-Setting Role of Mass Media", Public Opinon Quarterly, 36(2), 176-187

Negrusa, A. and Toader, V. (2014), Study of Romanian pilgrimage tourism supply, In: Cosma, S., Tutunea, M. and Petrescu, C. (eds.), Trends in Hospitality conference proceedings, Cluj-Napoca, Romania

Vedlinger, D. (2005), Introduction, In Price Grieve, G: and Veidlinger, D. (eds.), Buddhism, the Internet, and Digital Media, The Pixel in the Lotus, New York \& London, Routledge, 1-20

\section{Internetes források:}

https://cognitivecreators.com/Pope-Francis-2019-visit-to-Transylvania?fbclid=IwAR3hkMS7kQtb0v75J3xWdrE8w5tEMSmLCtoEXI-FQ61OdAxHWDqZBuxboi4 (Utolsó letöltés: 2020.02.10.)

https://issuu.com/hargita_kultura/docs/ hargitaimegyenapokmusorfuzet 2019 ff5633adc6f788? fbclid=IwAR0HIi6iSg3LZog5KGsPOF5LhxWZIPbPZRTk7dwaXErjCvAD91Oj1xP2NwQ (Utolsó letöltés: 2020.02.10.)

https://www.facebook.com/ADI.Harghita/photos/ pcb.2143173905731535/2143168869065372/ ?type $=3 \&$ theater (Utolsó letöltés: 2020.02.10.)

https://www.facebook.com/pontifex.ro/photos/a.82 $4581061229375 / 877945262559621 /$ type $=3 \&$ theater (

Utolsó letöltés: 2020.02.10.)

https://www.magyarkurir.hu/hirek/lenyugozoen-szep-kiadvannyal-emlekezik-erdelyi-magyar-egyhaz-ferenc-papa-csiksomlyoi-latogatasara (Utolsó letöltés: 2020.02.10.)

https://www.vaticannews.va/hu/papa/news/201909/ferenc-papa-romania-csiksomlyo-erdelyi-delegacio-koszonet.html (Utolsó letöltés: 2020.02.10.)

https://www.maszol.ro/index.php/tarsadalom/113735-eg-es-fold-kozott-ferenc-papavalrepult-a-maria-radio-munkatarsa (Utolsó letöltés: 2020.02.10.) 
Kádár Beáta $\mathrm{PhD}$, adjunktus kadarbeata@uni.sapientia.ro

Nagy Benedek PhD, adjunktus, tanszékvezető nagybenedek@uni.sapientia.ro

Sapientia - Erdélyi Magyar Tudományegyetem Czíkszeredai Kar

Üzleti Tudományok Tanszék

\section{The 2019 visit of Pope Francis in Csíksomlyó: reflections on the press articles}

\section{THE AIMS OF THE PAPER}

Our study is part of a larger, more complex research, which aimed to describe and analyze the events of the historical visit of Pope Francis in Transylvania, at Csíksomlyó (Sumuleu-Ciuc). The present study's main objective is to outline how the international and the (local) national press actors presented the event. It is an important issue, how much space was allocated for the presentation of the Csík or Szeklerland region, or for the religious and national-historical importance of the Csíksomlyó pilgrimage site. It is also interesting how the different national press treats the problem. Another goal of our research is to check the communication activities within the region, before and after the event, from the main actors (organizers) of the pope's visit.

\section{METHODOLOGY}

Our methods will be the quantitative and qualitative content analysis of a more than a hundred collected articles.

\section{MOST IMPORTANT RESULTS}

Although there are printed and online contents that function as region marketing, those rarely reach the target groups in time. Comprehensive marketing concepts and communication goals were not set based on the characteristics of the region, on the life and traditions of the local society or any other subject. The media covered the papal visit to Csíksomlyó in detail, however the reports focused mainly on the message of the pope or maybe on current politics but the Szekler region was rarely mentioned. In the Romanian press there were particularly few remarks on the ethnic-religious nature of the subject, since the current political climate is not quite favourable to minorities and cannot be considered Hungarian-friendly.

\section{RECOMMENDATIONS}

It is important that events of this nature are recognized as opportunities when it comes to marketing and communication. These events are great opportunities to promote the many possibilities this region has to offer and to attract tourists not just to the respective event itself but to the region too.

Keywords: pope's visit, Csíksomlyó/Sumuleu/Schomlenberg, press analysis, content analysis, regional image, $\mathrm{KH}$ Coder 